\title{
10. 中学生の歯列弓ならびに口蓋の逐年的発育の研究
}

\section{2. 年令別男女間の差}

Annual Increment of Various Oral Traits in Subjects from Twelve

to Fourteen Years of Age

II. Difference between Sexes

九州歯科大学口腔衛生学教室 (指導 : 荷宮文夫教授)

河野好彦

中学生に拈ける雨列弓ならびに口蓋の発育について 逐年的研究を行なっている。すでに本年10月口腔衛生 学会に扎いて,これらの発育量について報告した。今 回は歯列弓ならびに口蓋の大きさについて，男と女の 差を観測した。これらの成續の概要を報告する.

\section{資料}

研究に用いた対象は，大牟田市中学生，昭和38年 4 月に入学した 1 年男 100 名，女 105名である. 対象の 印象口腔石膏模型を38年, 39年, 40年の毎年 4 月に採 得した。この模型上で觀測を行なった。

\section{観測項目之観測方法}

観測した項目は，体格，頭，顔，崡列弓幅，下顎歯 槽幅, 歯列弓長, 歯列弓の長さ, 歯列弓周長, 切歯咬 交度, 切歯被蓋度, 口蓋幅, 口蓋弓隆長, 口蓋正中縫 合線長, 掞よび口蓋高などである．観测方法はMartin， Korkhous，执よび荷宮の方法によった。

\section{観測値の取扱い}

観測項目別に観測値を男女別年令別に平均値之变量 分散を出した，同一資料をくりかえし 3 回用いるため 各回の間に観測值の相関性があり，年令間の比較はこ の統計值を別に処理しなければ，二つの平均値の差の 検定が出来ない，発育量はすでに発表した通りで，各 人毎に観測值から1年間に抽汀る発育量を出して行な った。

観測した各項目の12才，13才，および14才の各年令 に和ける男と女の二つの平均值の差を検定した．項目 毎に各年令の男と女の变量分散の検定を行なった．母 分散が等しいか，否かをみた．母分散が等しいとき， 二つの標本平均值の差の検定は， $\mathrm{t}$ 一分布により行な った．母分散が等しくないときには，Cochran-Cox 近似法に上り検定した.

\section{成 績}

1 、歯列弓幅

歯列弓幅は12才，13才，执よび14才の男と女の各年 令とも，上，下頡の犬歯部がもっとも小さく，後方の
部位になるにつれて大きくなっている，上顎：12才の 男は女よりも平均 $1.4 \mathrm{~mm} \sim 2.3 \mathrm{~mm}$ 大きく，13才では男が 女よりも平均 $1.7 \mathrm{~mm} \sim 2.5 \mathrm{~mm}$ 大きく，14才には男が女よ りむ平均 $1.6 \mathrm{~mm} \sim 2.5 \mathrm{~mm}$ 大である.下顎：12才には男が 女より平均 $0.5 \mathrm{~mm} \sim 1.9 \mathrm{~mm}$ 大きく，13才には男が女より も平均 $1.5 \mathrm{~mm} \sim 1.9 \mathrm{~mm}$ 大きく，14才には男が女よりる平 均 $0.6 \mathrm{~mm} \sim 2.0 \mathrm{~mm}$ 大である. 男女とも各歯列弓幅はい ずれも同部位のむのは，上顎が下靧よりも大である.

2. 歯列弓の長さ

男女の各年令とも犬歯部がもっとも小さく，後方に なるにつれて大きくなっている，上下顎の同部位では 上顎が下顎より大である。上顎：12才には男が女より も平均 $0.9 \mathrm{~mm} \sim 1.7 \mathrm{~mm}$ 大きく，13才には同じく男が平均 1.0mm〜2.4mm大で，14才には男が女よりも平均 $1.0 \mathrm{~mm}$ 〜2.0mm大である. 下顎：各年令とも男が女より大き く，その差は12才に平均 $0.5 \mathrm{~mm} \sim 1.9 \mathrm{~mm}$ ，13才に平均 $0.4 \mathrm{~mm} \sim 1.8 \mathrm{~mm}, 14$ 才に平均 $0.2 \mathrm{~mm} \sim 1.7 \mathrm{~mm}$ である.

3. 口 蓋 幅

口蓋幅は各年令とも男が女よりも大きく，その差は 12 才に平均 $1.1 \mathrm{~mm} \sim 2.0 \mathrm{~mm}$ ，13才に平均 $1.3 \mathrm{~mm} \sim 2.0 \mathrm{~mm}$ ， 14 才に平均 $0.9 \mathrm{~mm}$ 〜 $2.2 \mathrm{~mm}$ である. 口蓋幅は各部位とも 男が女よりも大きく, 男女の各年令とも前方から後方 へと大きくなっている。

\section{4. 下顎歯槽幅}

下顎歯槽幅は男が女よりも大きく，その差は12才に 平均 $0.8 \mathrm{~mm} \sim 2.4 \mathrm{~mm}, 13$ 才に平均 $0.7 \mathrm{~mm} \sim 1.6 \mathrm{~mm}, 14$ 才に 平均 $0.4 m m \sim 1.4 m m$ である. 男女ともに前方から後方に 大きくなっている。

5 . 歯列弓長

上顎：前歯列弓長では，12才は男が女よりも平均 $0.3 m m$ 大きく，13才は平均 $0.9 \mathrm{~mm} ， 14$ 才は0.9mmで 男が 大である. 後崡列弓長では, 男が女よりも12才に平均 $1.1 \mathrm{~mm}, 13$ 才に平均 $1.6 \mathrm{~mm}$, 14才に 平均 $3.1 \mathrm{~mm}$ である.

下顎 : 前, 後雪列弓長とも各年令とも男が女よりも 大きく，その差は前歯列弓長では，12才に 平均 $0.5 \mathrm{~mm}$ 
10. 中学生の歯列弓ならびに口蓋の逐年的発育の研究

11. 17-7 Precipitation-Hardenablestainless steelの補綴応用について

13才に平均 $0.2 \mathrm{~mm}$ ，14才に平均 $0.2 \mathrm{~mm}$, 後歯列弓長 は，12才に平均 $0.5 \mathrm{~mm} ， 13 才 に$ 平均 $0.5 \mathrm{~mm}$ ，14才に平 均 $0.5 m m$ である.男女の同部位の朄列弓長では，上顎 が下顎よりも大である。

6. 口蓋弓隆長

12才では犬歯部と小四歯部は男が女よりも平均 0.1 $m m \sim 0.7 m m$ 大, 大曰電部は平均 $0.2 m m \sim 0.7 m m$ 女が男よ り大である.13才では第一大目部が女よりも平均 0.3mm大き ，他の部位は男が女よりも平均 $0.3 m m \sim$ 0.6mm大である. 14才は男が女より平均 $0.1 m m \sim 0.7$ mm大である。

口蓋弓隆長恃各年令とも前方より後方に大きく，が いして男が女より大である。

\section{7. 口蓋 高}

前口蓋高：12才から 14才までは 男が女よりも平均
$0.6 m m \sim 0.8 m m$ 高い.

後口蓋高：女が男よりむ平均 $0.8 \mathrm{~mm} \sim 1.4 \mathrm{~mm}$ 大であ る.

\section{8. 口蓋正中繾合線}

男が女よりも平均 $0.2 m m \sim 0.3 m m$ 大である.

結 果

中学生12才より14才までに括ける，宩列弓と口蓋の 大きさについて, 同一人を使って, 各年令に拈ける男 と女との差を比較した。

歯列弓幅, 口蓋幅, 下顎歯槽幅, 歯列弓の長さ, 拉 よび歯列弓長は，12才，13才，拈よび14才のいずれむ 男が女よりる大である。蓋弓隆長は12才，13才，抹 よび14才に和いていずれも男女間の差は著しくない。 口蓋高は各年令とも女がや〉高い(抄録)。

\section{17-7 Precipitation-Hardenable stainless steel の補綴応用について}

Application of 17-7 Precipitation-hardenable Stainless Steel in Prosthetic Dentistry

指導：九州歯科大学第 2 補緅学教室 松本洋一教授 東京医歯大 第 2 理工学教室 神沢康夫教授

九州歯科大学 第 1 補緅学教室 (主任 : 松本洋一教授)

自

\section{[I] 緒言}

雪科鈎用金属材料として各種系統の合金が応用され ているが，現在の鈎用金属材料としては臨床的に白金 加金線が最良とされている. 白金加金線の特徴は軟化 状態で柔らかく鈎に形成適合させるのが容易であり， 簡単な熱処理で充分な硬化を示し然かも伸びがあると いら点であるう。鈎用金属材料としては機械的性質か ら良否を決定するのは甚だ不満足な事ではあるが臨床 的に複雑な要素が加わり，はっきりした数值が出せな い以上現在臨床で使用し術者及び患者から最良とされ ている白金加金線に近い性質を目標にする外はない。
見

忠

Chemical composition of specimens.

\begin{tabular}{|c|c|c|c|c|c|c|c|c|}
\hline $\mathrm{C}$ & $\mathrm{S}$ & $\mathrm{Mn}$ & $\mathrm{P}$ & $\mathrm{S}$ & $\mathrm{Ni}$ & $\mathrm{Cr}$ & $\mathrm{Al}$ & $\mathrm{Fe}$ \\
\hline 0.007 & 0.65 & 0.81 & 0.023 & 0.013 & 7.22 & 17.32 & 1.03 & 73.864 \\
\hline
\end{tabular}

(weight \%) 